\title{
Effect of closed areas on populations of sea star Asterias spp. on Georges Bank
}

\author{
Michael C. Marino $\mathrm{II}^{1,2,{ }^{*}}$, Francis Juanes ${ }^{3}$, Kevin D. E. Stokesbury ${ }^{1,2}$ \\ ${ }^{1}$ Department of Fisheries Oceanography, University of Massachusetts Dartmouth, and \\ ${ }^{2}$ University of Massachusetts School of Marine Sciences, 706 South Rodney French Boulevard, New Bedford, \\ Massachusetts 02744-1221, USA \\ ${ }^{3}$ Department of Natural Resources Conservation, University of Massachusetts, Amherst, Massachusetts 01003-9285, USA
}

\begin{abstract}
High sea scallop abundances such as those in the closed areas of Georges Bank may cause predators, including sea stars, to aggregate and cause increased natural mortality rates for sea scallops. We hypothesized that sea stars are aggregated and are of larger size in areas of Georges Bank that are closed to fishing. Between 1999 and 2003, we systematically video surveyed 3809 stations (4 quadrats per station) in areas open and closed to fishing on Georges Bank. Sea stars were aggregated within the closed areas from 2000 to 2003. Sea star densities were higher in the closed areas than in the open areas during each year from 2000 to 2003 . The average arm length of sea stars within the open areas was not always smaller or larger than those in the closed areas; however, average arm length estimates were influenced by the abundance of sea star recruits. Sea scallop densities were independent of sea star densities. Sea star predation influenced sea scallop densities in specific locations, as instantaneous natural mortality rates were high.
\end{abstract}

KEY WORDS: Sea star · Asterias spp. · Sea scallop · Placopecten magellanicus $\cdot$ Closed areas Georges Bank · Video survey

\section{INTRODUCTION}

Sea stars have influenced scallop evolution, in that scallops are among the most efficient bivalve swimmers, and this swimming has primarily evolved to avoid sea star predation (Caddy 1989, Brand 1991). In the western North Atlantic, sea stars Asterias spp. and sea scallops Placopecten magellanicus are linked in a predator-prey relationship throughout their life history. For example, spawning and settlement are synchronized (Parsons et al. 1989), sea stars inflict varying rates of predation over a variety of substrates and scallop densities (Barbeau \& Scheibling 1994, Wong \& Barbeau 2003), and occasionally inflict mass mortalities removing $>25 \%$ of the scallop population (Dickie \& Medcof 1963).

High sea scallop abundance may cause predators, including sea stars, to aggregate (Merrill \& Posgay 1964, Caddy 1989, Orsensanz et al. 1991). In 1994,
3 large areas (total area closed ca. $17000 \mathrm{~km}^{2}$ ) of Georges Bank were closed to all mobile fishing gear, including scallop dredges, to protect declining groundfish stocks (Murawski et al. 2000). Sea scallop densities in these areas are presently among the greatest ever observed (Stokesbury 2002, Stokesbury et al. 2004).

We compared the densities, spatial distributions, and size structures of sea stars in closed and open areas of Georges Bank. We tested the hypotheses that: (1) sea stars are aggregating in the closed areas; (2) sea stars are larger in the closed areas than in the open areas; and (3) sea star predation on sea scallops is site-specific, causing high levels of localized natural mortality. We used video survey techniques to quantify the density, spatial distribution (on the scale of meters and kilometers), and size structure of sea scallop and sea stars, and the natural mortality rate of sea scallops. 


\section{MATERIALS AND METHODS}

Georges Bank is a submerged archipelago off the New England US coast and has supported historic scallop fishing grounds that extend from 13 to $150 \mathrm{~m}$ in depth along most of its circumference. Areas of high sea scallop densities, based on discussions with New Bedford scallop fishers and literature, were video surveyed, particularly within the 3 closed areas (Stokesbury 2002). The video survey was primarily designed to examine the distribution and abundance of sea scallops (Stokesbury 2002, Stokesbury et al. 2004); however, a secondary goal was to observe the distribution and abundances of other macroinvertebrates, including sea stars. Survey stations were positioned using a centric systematic design, as it is simple and samples evenly across the entire survey area (Krebs 1999, Stokesbury 2002). During the 1999 to 2002 surveys, 2885 video stations (11540 quadrats of $2.8 \mathrm{~m}^{2}$ ) were sampled on a grid with $1.57 \mathrm{~km}$ between stations (Fig. 1, Stokesbury 2002). In 2003, the sampling grid was expanded to include historical and present fishing grounds, with 924 video stations (3696 quadrats of $2.8 \mathrm{~m}^{2}$ ) on a grid with $5.60 \mathrm{~km}$ between stations (Fig. 1, Stokesbury et al. 2004). The total area surveyed within each sample area varied temporally (Table 1). The precision of this survey design ranged

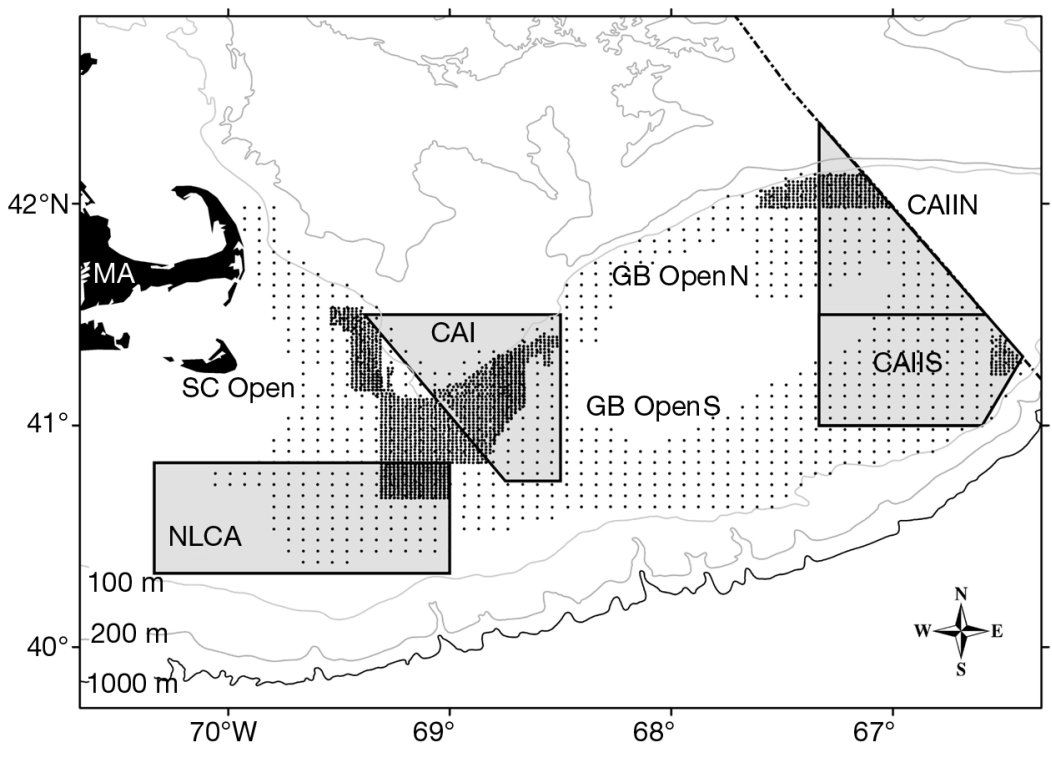

Fig. 1. Video survey sampling grid on Georges Bank, east of Massachusetts (MA), USA, from 1999 to 2003. Areas surveyed from 1999 to 2002 were sampled on a grid with $1.57 \mathrm{~km}$ between each station (denser dots). The grid was increased to $5.60 \mathrm{~km}$ between each station in 2003 (less dense dots). Closed Area I (CAI), Closed Area II north and south (CAIIN and CAIIS), and Nantucket Lightship Closed Area (NLCA) have been closed to all mobile fishing gear since 1994 (shaded). The northern and southern portions of the open area of Georges Bank (GB OpenN and GB OpenS), and the South Channel (SC Open) have been continuously open to fishing from 5 to $15 \%$ for the normal and negative binomial distributions, respectively, for sea scallop densities assessed in the Nantucket Lightship Closed Area (NLCA) in 1999 (Stokesbury 2002).

A video sampling pyramid (described in Stokesbury 2002, Stokesbury et al. 2004) was deployed from scallop fishing vessels. Two downward-looking cameras provided 2.8 and $0.6 \mathrm{~m}^{2}$ (nested within the $2.8 \mathrm{~m}^{2}$ ) views of the sea floor; however, only the data from the $2.8 \mathrm{~m}^{2}$ view were used in the analysis. A third camera provided a profile view of the sea floor and was used for species identification. It was possible to identify sea scallops and sea stars to a minimum size of about $20 \mathrm{~mm}$, and all individuals were counted, including those that were only partially visible along the edge of the quadrat image. To correct for this edge effect, $56 \mathrm{~mm}$, based on the average shell height of the scallops observed, were added to each edge of the quadrat image so that the quadrat size was effectively $3.24 \mathrm{~m}^{2}$ (Stokesbury 2002, Stokesbury et al. 2004). Four quadrats were observed at each station, which increased the sample area to $12.94 \mathrm{~m}^{2}$.

Monitors and S-VHS video recorders for each camera, a monitor for the Captain who controlled the vessel's hydraulic winches to deploy the pyramid, a laptop computer with Arcpad GIS ${ }^{\circledast}$ software integrated with a differential global positioning system, and a laptop computer for data entry, were assembled in the wheelhouse. The survey grid was plotted prior to the cruise in Arcpad GIS $^{\circledR}$. Video footage of the sea floor was recorded on S-VHS videotapes. For each quadrat, we recorded the time, depth, latitude and longitude, number of scallops and clappers (scallops that died of natural causes), substrate, and the presence of other macroinvertebrates (including sea stars).

After each survey the videotapes were reviewed in the laboratory and a still image of each quadrat was digitized and saved using Image Pro Plus ${ }^{\circledR}$ software (TIFF file format). Counts of sea stars and sea scallops were standardized to individuals $\mathrm{m}^{-2}$. The sea stars Asterias vulgaris (= A. rubens, Franz et al. 1981) and A. forbesi are sympatric species on Georges Bank, and the feeding ecology and movement of both species are similar (Feder \& Moller-Christensen 1966). Franz et al. (1981) observed that A. forbesi are largely confined to the inner shelf and were rarely collected on Nantucket Shoal and Georges Bank, whereas $A$. vulgaris occur over the entire breadth of the continental shelf from the 
Table 1. Asterias spp. Mean sea star densities $( \pm \mathrm{SE})$ in open and closed areas of Georges Bank between 1999 and 2003. Sea star spatial distributions were estimated using the index of dispersion 'variance $\left(s^{2}\right)$ to mean ratio' and by comparing the observed sea star distributions to those predicted by the Poisson (random; $\mathrm{p}<0.001$ for all areas in all years) and negative binomial (neg. bin; aggregated) distributions using chi-square analysis (Elliott 1971). Agreement of $s^{2}$ :mean with the Poisson series was rejected at the $99 \%$ probability. CAI: Closed Area I; CAIIN, CAIIS: Closed Area II north and south, respectively; GB OpenN, GB OpenS: southern and northern portions of the open area on Georges Bank, respectively; NLCA: Nantucket Lightship Closed Area; SC Open: South Channel

\begin{tabular}{|lccccc|}
\hline Area & Stations & Density $\left(\mathrm{m}^{-2}\right)$ & $s^{2}$ :mean & $\begin{array}{c}\text { p-values (chi-square) } \\
\text { df }\end{array}$ & Neg. bin. \\
\hline 1999 & & & & & \\
CAI & 455 & $0.09 \pm 0.009$ & 4.66 & 14 & 0.084 \\
CAIIN & 125 & $0.09 \pm 0.012$ & 2.16 & 7 & 0.758 \\
NLCA & 205 & $0.32 \pm 0.038$ & 9.73 & 25 & 0.031 \\
2000 & & & & & \\
CAI & 183 & $0.15 \pm 0.020$ & 4.89 & 14 & 0.423 \\
NLCA & 204 & $0.12 \pm 0.016$ & 4.82 & 13 & 0.296 \\
SC Open & 157 & $0.06 \pm 0.009$ & 2.21 & 6 & 0.413 \\
2001 & & & & & \\
CAI & 164 & $0.13 \pm 0.016$ & 3.51 & 11 & 0.099 \\
CAIIN & 162 & $0.03 \pm 0.011$ & 7.18 & 5 & 0.709 \\
GB OpenN & 115 & $0.04 \pm 0.016$ & 8.17 & 5 & 0.742 \\
CAIIS & 62 & $0.12 \pm 0.058$ & 18.13 & 7 & 0.220 \\
NLCA & 204 & $0.28 \pm 0.032$ & 7.67 & 21 & 0.923 \\
SC Open & 201 & $0.03 \pm 0.006$ & 2.13 & 4 & 0.735 \\
2002 & & & & & \\
NLCA & 204 & $0.43 \pm 0.046$ & 10.46 & 27 & 0.358 \\
SC Open & 444 & $0.07 \pm 0.006$ & 2.41 & 8 & 0.989 \\
2003 & & & & & \\
CAI & 97 & $0.09 \pm 0.023$ & 6.20 & 8 & 0.061 \\
CAIIN & 72 & $0.02 \pm 0.008$ & 2.13 & 2 & 0.009 \\
CAIIS & 114 & $0.20 \pm 0.081$ & 39.20 & 14 & 0.097 \\
GB OpenN & 114 & $0.21 \pm 0.050$ & 14.44 & 12 & 0.566 \\
GB OpenS & 196 & $0.46 \pm 0.051$ & 11.42 & 29 & 0.428 \\
NLCA & 128 & $1.67 \pm 0.254$ & 51.93 & 40 & 0.045 \\
SC Open & 203 & $0.30 \pm 0.056$ & 21.90 & 25 & 0.482 \\
& & & & & \\
\hline
\end{tabular}

areas open and closed to fishing. Sea star spatial distributions were evaluated using the index of dispersion (the variance, $s^{2}$, to mean ratio) and by comparing distributions to those predicted by the Poisson (random) and negative binomial (aggregated) distributions with chi-square analyses, applying Cochran's rule when the expected count was less than 5 (Elliott 1971, Zar 1999). Distributions were determined for the areas surveyed each year to determine if sea stars were aggregating on the scale of $10 \mathrm{~s}$ of $\mathrm{km}^{2}$. Aggregations less than $1.57 \mathrm{~km}$ were undetectable, as the aggregation pattern is dependent on the grid size.

Sea star density data were tested for normality and homogeneity of variance using Kolmogorov-Smirnov tests and Levene's median tests, respectively (Zar 1999). In most cases the hypothesis was rejected; however, untransformed data were used because transformations had a limited effect (Underwood 1981). Normality was not considered a serious issue, as sample sizes were reasonably large (Zar 1999). Comparisons of means were made with Welch's approximate $t$-tests $\left(t^{\prime}\right)$, which did not assume equal variances, with awareness of increased probability of Type I error (Day \& Quinn 1989, Underwood 1997, Zar 1999). Sea star density comparisons were not made in 1999, as areas open to fishing were not video surveyed in that year.

Bay of Fundy to Maryland. Most of the observed sea stars were therefore believed to be A. vulgaris, but differences between the 2 species were not detectable in the video images, so the 2 species were combined (Asterias spp.).

The mean and SE for the density (ind. $\mathrm{m}^{-2}$ ) of sea stars and sea scallops were calculated using equations for a 2-stage sampling design (Cochran 1977, Stokesbury 2002). Sea star abundance within a survey area was estimated by multiplying the mean number of sea stars $\mathrm{m}^{-2}$ by the total area surveyed (Stokesbury 2002, Stokesbury et al. 2004).

Sea scallop shell heights ( $\mathrm{mm}$; from the umbo to the ventral shell edge) and sea star arm lengths ( $\mathrm{mm}$; from the tip of a median sized arm to the center of the oral disc) were measured using Image Pro Plus ${ }^{\circledR}$ software.

To test the hypothesis that sea stars were aggregating in the closed areas, we examined differences in the spatial distribution and densities of sea stars between
We examined the effect of area type on sea star density by applying a 1-way nested ANOVA to the $5.60 \mathrm{~km}$ grid survey data set from 2003. The area type (open and closed) was the experimental factor and survey area (Closed Area I [CAI], Closed Area II north and south [CAIIN, CAIIS], Nantucket Lightship Closed Area [NLCA], Georges Bank Open north and south [GB OpenN, GB OpenS], and South Channel [SC Open]) was the nested factor.

The $5.60 \mathrm{~km}$ grid survey conducted in 2003 examined sea star distributions at depths between 13 and $150 \mathrm{~m}$, and covered areas with and without sea scallops (Fig. 2). A 1-factor ANCOVA was used to test for differences in sea star densities between areas closed and open to fishing, after removing the effects of depth and sea scallop density. The ANCOVA included sea star density as the dependent variable, area as the categorical variable, and water depth and sea scallop density as separate independent variables. The homo- 
geneity of regression slopes assumption was tested by ANOVA, including the covariate and examining the significance of the interaction term (Huitema 1980). The survey area-sea scallop density interaction did not have a significant effect on sea star density $\left(F_{6,910}=\right.$ $1.76, \mathrm{p}=0.185)$. There was a significant effect of the survey area-depth interaction on sea star density $\left(F_{6,910}=9.68, \mathrm{p}<0.001\right)$. Therefore, the assumption of homogeneity of slopes was violated, so depth was not used as a covariate in the ANCOVA (Huitema 1980, Underwood 1981).

Chi-square analysis, applying Yates' correction, was also used to determine if sea stars were more abundant in closed areas than in open areas within each year surveyed (2000 to 2003) (Zar 1999). The number of stations where sea stars were observed compared to the total number of stations surveyed provided the percentage of stations with sea stars, which was used to standardize for differences in the number of stations sampled. The number of stations surveyed in CAI in 1999 was higher than in 2000 and 2001; therefore, only stations that were repeatedly sampled were used in the analysis.

We compared mean sea star arm lengths with Welch's approximate $t$-test to test the hypothesis that sea stars were larger in the closed areas than in the open areas. Comparisons were made spatially, between areas surveyed in the same year, and temporally, between years for surveys in the same area. A 1-way nested ANOVA was used to examine the effect of the type of area on sea star arm length in 2003. The type of area was the experimental factor and survey area was the nested factor.

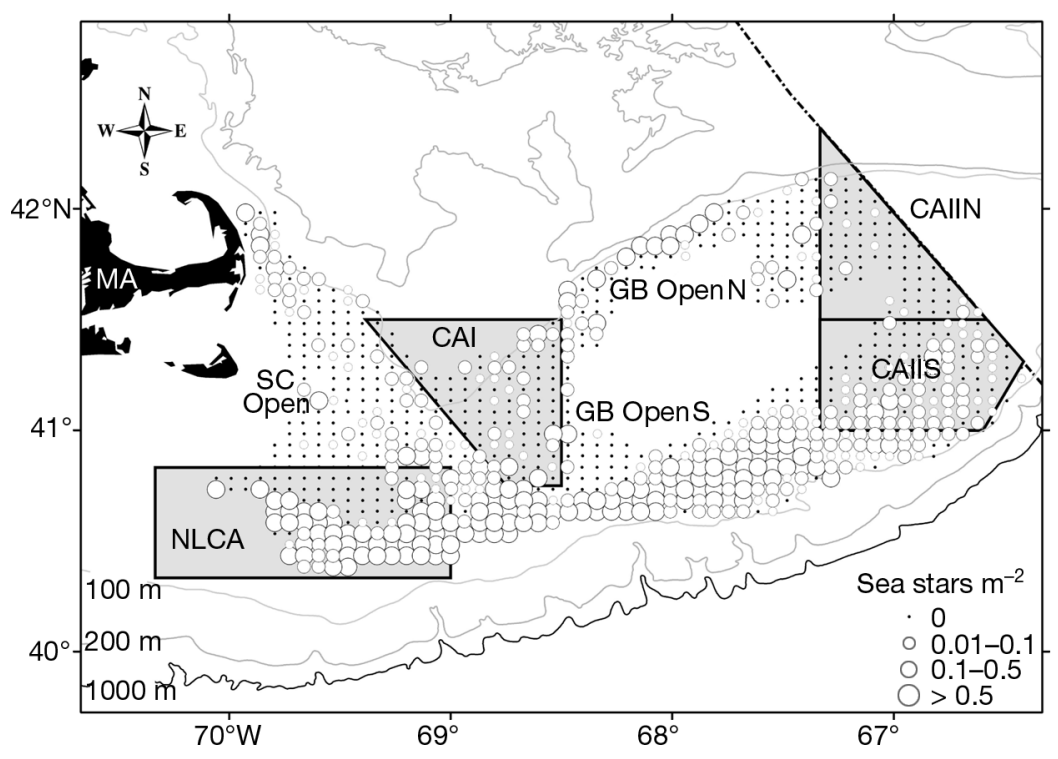

Fig. 2. Asterias spp. Sea star densities (sea stars $\mathrm{m}^{-2}$ ) on Georges Bank observed during the 2003 video survey. Area labels are defined in Fig. 1
We examined the spatial and temporal variations of sea scallop natural mortality rates within areas open to and closed to fishing to test the hypothesis that sea star predation on sea scallops was site specific, causing high levels of localized natural mortality. The annual rate of sea scallop natural mortality (a) was calculated as (Dickie 1955, Merrill \& Posgay 1964):

$$
a=1-\mathrm{e}^{-(\mathrm{C} / t)(1 / L)(365)}
$$

where $C$ : the number of clappers (scallops that died of natural causes including sea star predation) in a sample, which were easily identifiable in the video images because their 2 shells were still attached by the umbo ligament (Stokesbury 2002), $t$ : the average time (in days) required for the shell to separate, and $L$ : the number of live scallops in a sample. The exponent is equal to the instantaneous natural mortality rate $(M)$. Merrill \& Posgay (1964) found that the average time of ligament separation is $33 \mathrm{wk}$, but varies depending upon the environmental conditions; therefore, the exponent becomes $(C / L) \times 1.58$. We applied this equation to the video observations to determine the spatially specific natural mortality rate in different areas of Georges Bank.

\section{RESULTS}

Sea stars had a contagious (aggregated) distribution in all areas surveyed and in all years. The indices of dispersion suggested an aggregated pattern at the scale of $10 \mathrm{~s}$ of $\mathrm{km}$, as they differed from the Poisson distribution, and agreed with the negative binomial distribution in all survey areas except NLCA in 1999 and 2003 and CAIIN in 2003 (Table 1).

Sea star densities were greater in the closed areas $\left(0.13\right.$ to $\left.0.60 \mathrm{~m}^{-2}\right)$ than in open areas (0.04 to $0.34 \mathrm{~m}^{-2}$ ) during each year from 2000 to 2003 (Table 2). There was a significant effect of survey area within the type of area in 2003 (Table 3, p < 0.001). There was no effect of area type on the density of sea stars in 2003 (Table 3, p = 0.72). Comparisons between specific sites showed a more variable pattern. Sea star densities were higher in NLCA and CAI than in the open areas from 2000 to 2002 (Tables 1 \& 4); however, sea star densities in CAIIN and CAIIS were similar to those in open areas in 2001. In 2003, NLCA had a very high density of sea stars (1.67 sea stars $\mathrm{m}^{-2}, \mathrm{SE}=$ $0.254)$, while densities in open areas ranged between 0.21 and 0.46 sea stars $\mathrm{m}^{-2}(\mathrm{SE}=$ 0.050 and 0.051 , respectively) and CAI and CAII ranged between 0.09 and 0.20 sea stars $\mathrm{m}^{-2}(\mathrm{SE}=0.023$ and 0.081 , respectively $)$ 
(Table 1). Sea star densities were highest in NLCA for each of the 5 years surveyed (Table 1), and higher in the open areas than those in CAI and CAIIN in 2003. Similarly, on the southern flank of Georges Bank (GB Open S), higher densities of sea stars were observed in the open area than in the adjacent closed area in 2003 (Tables 1 \& 4). Sea star densities in 2003 differed significantly between survey areas even when the density of sea scallops was taken into account (Table 5).

Chi-square analysis comparing the distributions in open and closed areas indicated that sea stars were not aggregating in the closed areas in the 2000 survey $\left(\chi^{2}=\right.$ 1.33, df $=1, p=0.250$ ), but were aggregated in the closed areas in the 2001, 2002, and 2003 surveys (2001: $\chi^{2}=25.23, \mathrm{df}=1, \mathrm{p}<0.001 ; 2002: \chi^{2}=38.98, \mathrm{df}=1, \mathrm{p}<$ $\left.0.001 ; 2003: \chi^{2}=4.40, \mathrm{df}=1, \mathrm{p}=0.04\right)$.

The area covered by sea star aggregations varied between areas and years, and area usually increased or decreased as the sea star density increased or de-
Table 2. Asterias spp. Mean sea star densities $\left(\mathrm{m}^{-2}\right)$ in the combined closed areas compared to those in the combined open areas for each year from 2000 to 2003 using Welch's approximate $t$-test $\left(t^{\prime}\right)$. Data from 1999 were omitted from this analysis since no open areas were sampled. 95\% CI: 95\% confidence interval

\begin{tabular}{|c|c|c|c|c|c|c|c|c|}
\hline \multirow{2}{*}{ Year } & \multicolumn{2}{|c|}{ _ Density _ _ } & \multirow[t]{2}{*}{$t^{\prime}$} & \multirow[t]{2}{*}{$\mathrm{df}$} & \multirow{2}{*}{$\mathrm{p}$} & \multirow{2}{*}{$\begin{array}{c}\text { Mean } \\
\text { difference }\end{array}$} & \multicolumn{2}{|c|}{$-95 \% \mathrm{CI}-$} \\
\hline & Closed & Open & & & & & Lower & Upper \\
\hline 2000 & 0.132 & 0.062 & 4.57 & 536 & $<0.001$ & 0.071 & 0.041 & 0.102 \\
\hline 2001 & 0.153 & 0.036 & 7.38 & 819 & $<0.001$ & 0.117 & 0.086 & 0.148 \\
\hline 2002 & 0.431 & 0.067 & 7.86 & 210 & $<0.001$ & 0.364 & 0.273 & 0.455 \\
\hline 2003 & 0.601 & 0.340 & 2.74 & 512 & 0.006 & 0.261 & 0.074 & 0.448 \\
\hline
\end{tabular}

Table 3. Asterias spp. Results of 1-way nested ANOVA applied to sea star density $\left(\mathrm{m}^{-2}\right)$ between closed and open areas on Georges Bank in 2003

\begin{tabular}{|lcrrrr|}
\hline Source & df & \multicolumn{1}{c}{ SS } & \multicolumn{1}{c}{ MS } & \multicolumn{1}{c|}{$F$} & \multicolumn{1}{c|}{$\mathrm{p}$} \\
\hline Fishery & 1 & 6.49 & 6.49 & 0.148 & 0.716 \\
Area & 5 & 221.38 & 44.28 & 29.002 & $<0.001$ \\
Residual & 917 & 1399.93 & 1.53 & & \\
\hline
\end{tabular}

Table 4. Asterias spp. Comparisons of mean sea star densities $\left(\mathrm{m}^{-2}\right)$ between closed and open areas on Georges Bank from 2000 to 2003 using Welch's approximate $t$-test $\left(t^{\prime}\right)$. Negative values of mean difference indicate that the density of sea stars was higher in the open area than in the closed area. Area labels are defined in Table 1

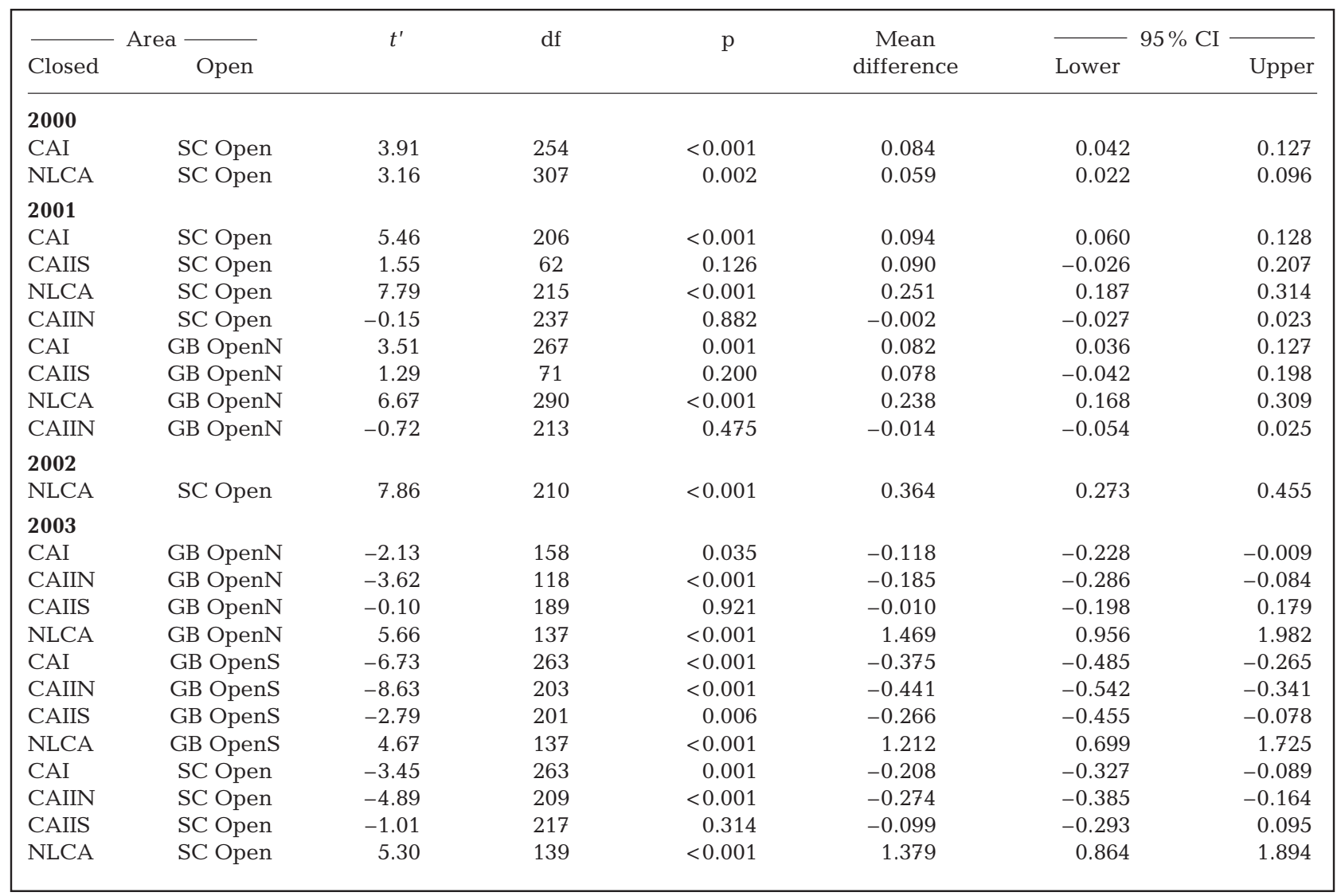


creased, respectively (Fig. 3). However, in CAI the area covered by the aggregations increased from $42 \%$ in 2000 to $46 \%$ in 2001, while the density decreased (Fig. 3).

The average sizes of sea stars varied among areas and years from 22.7 to $74.3 \mathrm{~mm}(\mathrm{SD}=31.62$ and 13.65, respectively) (Fig. 4). For example, mean sea star arm length in the SC Open was larger than in CAI and NLCA in 2000 and 2001 (Table 6). However, mean arm lengths were similar between NLCA and SC Open in 2002. The mean arm lengths in CAIIN and CAIIS were larger in 2001 than in each of the open areas, respectively (Table 6). There was no distinct pattern; for example sea stars in the open areas were not always smaller or larger than those in closed areas (Table 6, Fig. 4). There was a significant effect of survey area within the area type on sea star arm length in 2003 (Table 7, p < 0.001). There was no effect of area type on the arm length of sea stars in 2003 (Table 7, p = 0.294). A more variable pattern was observed in comparisons between specific sites.

Temporal variations of mean arm length were observed within each survey area. The mean arm length of sea stars in NLCA increased between 1999 and 2001 and decreased from 2001 to 2002 (1999 to 2000: $t^{\prime}=-4.91, \mathrm{p}<0.001 ; 2000$ to 2001: $t^{\prime}=-2.11, \mathrm{p}=$ 0.035; 2001 to 2002: $t^{\prime}=16.64, \mathrm{p}<0.001$ ) (Fig. 4). Mean arm length in CAI decreased from 1999 to 2000 and increased from 2000 to 2001 (1999 to 2000: $t^{\prime}=3.81$, p < 0.001; 2000 to 2001: $\left.t^{\prime}=-5.57, \mathrm{p}<0.001\right)$. Mean arm length in CAIIN also increased from 1999 to 2001 ( $t^{\prime}=$ $-3.754, p<0.001)$. However, mean arm lengths were constant in SC Open from 2000 to $2001\left(t^{\prime}=-0.43, \mathrm{p}=\right.$ 0.669) (Fig. 4).
The instantaneous natural mortality rate of sea scallops within our surveyed areas ranged from 0.00 to $0.18 \mathrm{yr}^{-1}$ (Table 8). The highest instantaneous mortality rates were observed in CAII and NLCA, but in general, mortality rates varied yearly and were often low (Table 8).

\section{DISCUSSION}

Sea stars were highly aggregated in areas both closed and open to fishing from 1999 to 2002 on the scale of $10 \mathrm{~s}$ of $\mathrm{km}$. Sea stars appeared to be more loosely aggregated in 2003, but this pattern may reflect the change in survey design; in 2003 we sampled a much larger portion of the continental shelf and there was a greater distance between stations.

On a large spatial scale, sea stars Asterias forbesi and A. vulgaris occur over the entire breadth of Georges Bank, with marked differences in densities related to depth, substratum, and temperature (Franz et al. 1981, Theroux \& Wigley 1998). Sea stars are distributed around the edges of Georges Bank and the South Channel at depths between 25 and $200 \mathrm{~m}$ but are rare in the central portion (Theroux \& Wigley 1998). Sea stars within this area are associated more with fine particle bottoms than with gravel and till (Theroux \& Wigley 1998). Sea stars are more abundant where temperature ranges are moderate $(4.0$ to $15.9^{\circ} \mathrm{C}$ ) but can tolerate, at least for short periods of time, temperatures as high as $25^{\circ} \mathrm{C}$ (Franz et al. 1981, Theroux \& Wigley 1998). Our sample area ranged from 13 to $150 \mathrm{~m}$ in depth within the sea star

Table 5. Asterias spp. and Placopecten magellanicus. Comparison of mean sea star densities $\left(\mathrm{m}^{-2}\right)$ between closed and open areas on Georges Bank in 2003 using a 1-way ANOVA and a 1-way ANCOVA with mean sea scallop density $\left(\mathrm{m}^{-2}\right)$ as a covariate. Adjusted means for sea star density were calculated for a mean sea scallop density of 0.15 scallops $\mathrm{m}^{-2}$. Area labels are defined in Table 1

\begin{tabular}{|c|c|c|c|c|c|c|}
\hline & & $\mathrm{df}$ & SS & MS & $F$ & $\mathrm{p}$ \\
\hline ANOVA (Area) & $\begin{array}{l}\text { Between groups } \\
\text { Within groups }\end{array}$ & $\begin{array}{c}6 \\
917\end{array}$ & $\begin{array}{c}236.908 \\
1399.925\end{array}$ & $\begin{array}{r}39.485 \\
1.527\end{array}$ & 25.864 & $<0.001$ \\
\hline ANCOVA (Area) & $\begin{array}{c}\text { Covariate (scallops) } \\
\text { Between groups } \\
\text { Within groups }\end{array}$ & $\begin{array}{c}1 \\
6 \\
916\end{array}$ & $\begin{array}{c}2.684 \\
238.363 \\
1397.241\end{array}$ & $\begin{array}{r}2.684 \\
39.727 \\
1.525\end{array}$ & $\begin{array}{r}1.759 \\
26.044\end{array}$ & $\begin{array}{r}0.185 \\
<0.001\end{array}$ \\
\hline Area & $\mathrm{n}$ & $\begin{array}{l}\text { ANOVA } \\
\text { Mean }\end{array}$ & SE & $\begin{array}{l}\text { ANCOV } \\
\text { Adjusted mean }\end{array}$ & $\mathrm{SE}$ & \\
\hline CAI & 97 & 0.09 & 0.023 & 0.09 & 0.125 & \\
\hline CAIIN & 72 & 0.02 & 0.008 & 0.04 & 0.146 & \\
\hline CAIIS & 114 & 0.20 & 0.081 & 0.21 & 0.116 & \\
\hline GB OpenN & 114 & 0.21 & 0.050 & 0.20 & 0.116 & \\
\hline GB OpenS & 196 & 0.46 & 0.051 & 0.46 & 0.088 & \\
\hline NLCA & 128 & 1.67 & 0.254 & 1.68 & 0.109 & \\
\hline SC Open & 203 & 0.30 & 0.056 & 0.29 & 0.087 & \\
\hline
\end{tabular}


range. Although we could not test the association between sea star distributions and depth due to violations in the assumptions of the analysis, significant differences between the survey areas were detected as the response to depth was different between areas.

Sea stars aggregated within the closed areas on Georges Bank. Although sea scallop densities were independent of sea star densities, they may be determined by sea star predation in specific locations where instantaneous sea scallop natural mortality rates were high. Sea stars may aggregate in closed areas for several possible reasons. Responses of predators to prey abundance include functional responses, where the consumption rates of individual predators increase, and aggregative numerical responses, where densities of predators increase (Barbeau et al. 1996). In seeding trials in Atlantic Canada, Asterias vulgaris showed a functional response to high sea scallop abundance, but not a numerical response (Cliché et al. 1994, Barbeau et al. 1996). However, Sloan (1984) suggests that most predatory sea stars are opportunistic and will aggregate on superabundant food sources: the sea stars Distelasterias nipon and $A$. rubens have been previously observed aggregating on high-density patches of the Japanese scallop Patinopecten yessoensis (Volkov et al. 1983, Caddy 1989) and the European queen scallop Pecten maximus (Wilson \& Brand 1994).

Our findings differ from previous research that suggests that the effect of fishing on the benthic community causes aggregations of opportunistic predators and scavengers to feed on prey damaged by fishing gear (Ramsay et al. 1998). Portions of CAIIS, NLCA, and CAI were opened from 1999 to 2000, in 2000, and from 2000 to 2001, respectively, for a short-term limited fishery (NMFS 1999-2001, Stokesbury \& Harris 2006). Sea stars were aggregated in closed areas and in some cases densities decreased after a fishing event. Although significant numbers of sea stars are collected by scallop dredges, they are returned to the sea after each dredge haul (K. D. E. Stokesbury et al. unpubl. data); therefore, scallop dredging would not explain decreased sea star densities. Spatial and temporal scales also vary greatly between studies. Previous studies examined this relationship on the scale of meters by studying the path of the dredge immediately after the dredge tow was made, whereas the present study was conducted on the scale of square kilometers and was conducted after the limited fishery was closed.

In the sea scallop fishery, the scallop abductor muscles are harvested immediately after capture and the remaining somatic tissue is returned to the ocean. These discards represent approximately $67 \%$ of the total soft tissue weight of the scallop, and may cause predators to aggregate (K.D.E. Stokesbury et al.
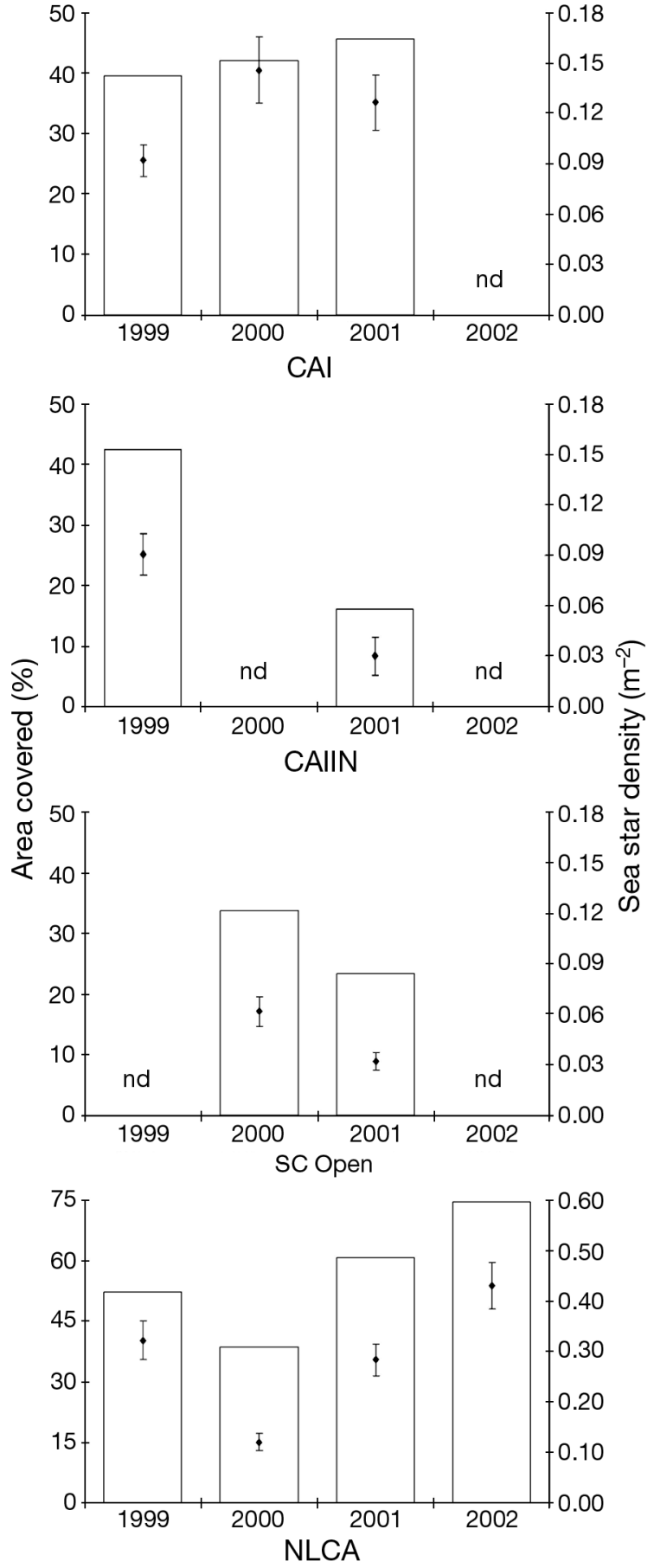

Fig. 3. Asterias spp. Percentage of area covered by aggregation (bars) and average sea star density (points) (SE) in areas closed and open to fishing on Georges Bank between 1999 and 2003. nd: no data collected; area labels are defined in Fig. 1

unpubl. data). In CAIIS, the 1999 to 2000 short-term limited fishery was intense and highly localized. Approximately 3483 metric tons (t) of abductor muscle was harvested and $10600 \mathrm{t}$ of soft tissue discarded. This limited fishery occurred at the same time as the 


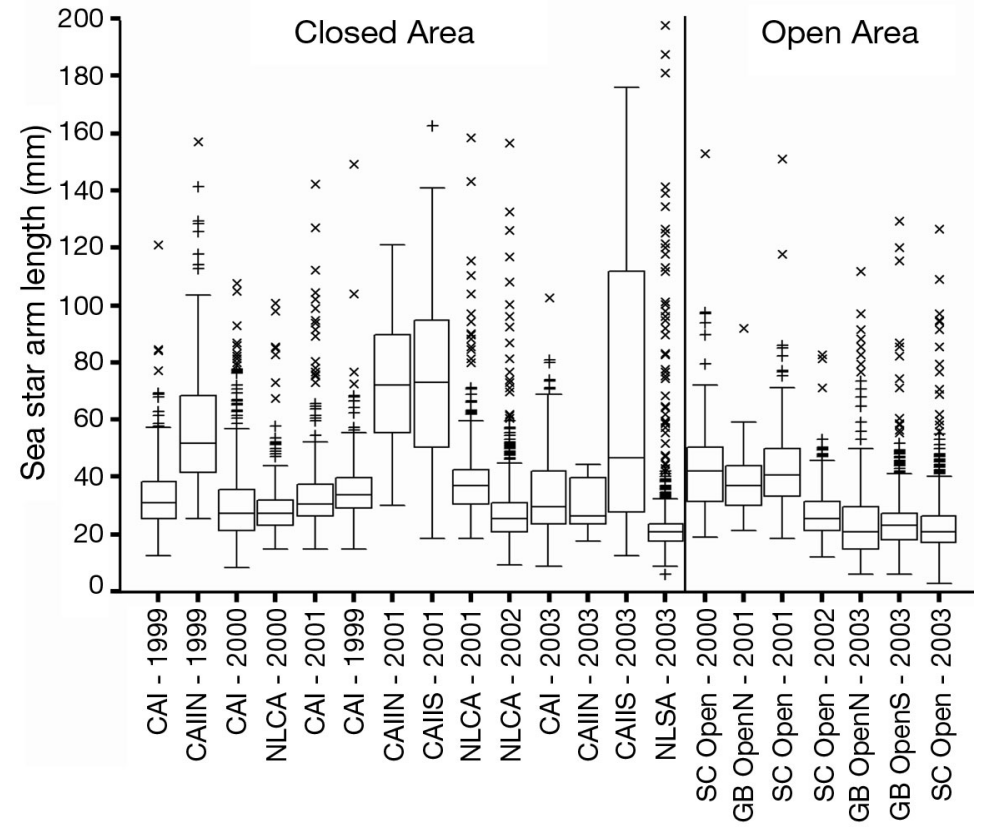

Fig. 4. Asterias spp. Sea star arm lengths $(\mathrm{mm})$ from 9038 sea stars observed at 3809 video survey stations (15 236 quadrats) on Georges Bank from 1999 to 2003. Each plot shows the median (solid horizontal line), the 25th and 75th percentiles (outer edges of the box), and the 10th and 90th percentiles (whiskers). +: outliers; ×: extreme values; area labels are defined in Fig. 1 settlement of juvenile Asterias vulgaris on Georges Bank (Barker \& Nichols 1983). The distribution of sea stars in CAIIS was highly aggregated, as indicated by the high coefficient of variation $(\mathrm{CV} \%=47.4)$, even though the mean density was similar to that in areas open to fishing. This suggests that the distribution of sea stars was patchy on a relatively small scale (10s of $\mathrm{m}^{2}$ ). An aggregated distribution was also indicated by the observation of extremely high densities of sea stars feeding on sea scallops in 2001 and 2003 (Fig. 5).

High densities of sea stars were not always associated with closed areas. Dynamic environmental conditions may explain the low densities of sea stars in CAIIN and the reduced area covered by the sea star aggregation. The northern flank of Georges Bank is characterized by rapidly changing water depth, a complex frontal zone, and strong currents (Flag 1987). The macrobenthic invertebrate faunal assemblage existing on the northern edge and northeast peak consists

Table 6. Asterias spp. Comparison of mean sea star arm lengths (mm) (see Fig. 4) between closed and open areas on Georges Bank from 2000 to 2003 using Welch's approximate $t$-test $\left(t^{\prime}\right)$. Negative values of mean difference indicate sea star arm lengths were larger in the open area than in the closed area. Area labels are defined in Table 1

\begin{tabular}{|c|c|c|c|c|c|c|c|}
\hline \multicolumn{2}{|c|}{${ }$ Area - } & \multirow{2}{*}{$t^{\prime}$} & \multirow{2}{*}{$\mathrm{df}$} & \multirow{2}{*}{$\mathrm{p}$} & \multirow{2}{*}{$\begin{array}{c}\text { Mean } \\
\text { difference }\end{array}$} & \multicolumn{2}{|c|}{$-95 \% \mathrm{CI}-$} \\
\hline Closed & Open & & & & & Lower & Upper \\
\hline \multicolumn{8}{|l|}{2000} \\
\hline CAI & SC Open & -7.23 & 128 & $<0.001$ & -14.901 & -18.981 & -10.821 \\
\hline NLCA & SC Open & -3.93 & 170 & $<0.001$ & -8.781 & -13.187 & -4.374 \\
\hline \multicolumn{8}{|l|}{2001} \\
\hline CAI & SC Open & -3.80 & 96 & $<0.001$ & -9.931 & -15.122 & -4.739 \\
\hline CAIIS & SC Open & 6.90 & 159 & $<0.001$ & 28.457 & 20.311 & 36.603 \\
\hline NLCA & SC Open & -3.02 & 82 & 0.003 & -7.567 & -12.555 & -2.578 \\
\hline CAIIN & SC Open & 6.52 & 93 & $<0.001$ & 27.782 & 19.322 & 36.241 \\
\hline CAI & GB OpenN & -1.00 & 33 & 0.327 & -2.761 & -8.406 & 2.887 \\
\hline CAIIS & GB OpenN & 8.43 & 101 & $<0.001$ & 35.627 & 27.242 & 44.012 \\
\hline NLCA & GB OpenN & -0.15 & 28 & 0.883 & -0.397 & -5.872 & 5.078 \\
\hline CAIIN & GB OpenN & 8.02 & 74 & $<0.001$ & 34.951 & 26.265 & 43.637 \\
\hline \multicolumn{8}{|l|}{2002} \\
\hline NLCA & SC Open & -0.32 & 776 & 0.752 & -0.204 & -1.471 & 1.062 \\
\hline \multicolumn{8}{|l|}{2003} \\
\hline CAI & GB OpenN & 4.35 & 194 & $<0.001$ & 8.268 & 4.518 & 12.018 \\
\hline CAIIN & GB OpenN & 1.58 & 30 & 0.124 & 3.440 & -0.993 & 7.873 \\
\hline CAIIS & GB OpenN & 14.18 & 330 & $<0.001$ & 43.944 & 37.848 & 50.040 \\
\hline NLCA & GB OpenN & -3.32 & 370 & 0.001 & -3.480 & -5.544 & -1.417 \\
\hline CAI & GB OpenS & 6.34 & 114 & $<0.001$ & 10.421 & 7.162 & 13.680 \\
\hline CAIIN & GB OpenS & 2.87 & 20 & 0.010 & 5.593 & 1.521 & 9.665 \\
\hline CAIIS & GB OpenS & 15.64 & 274 & $<0.001$ & 46.097 & 40.292 & 51.901 \\
\hline NLCA & GB OpenS & -3.03 & 2831 & 0.002 & -1.328 & -2.187 & -0.467 \\
\hline CAI & SC Open & 6.73 & 123 & $<0.001$ & 11.265 & 7.950 & 14.580 \\
\hline CAIIN & SC Open & 3.26 & 21 & 0.004 & 6.437 & 2.326 & 10.548 \\
\hline CAIIS & SC Open & 15.83 & 280 & $<0.001$ & 46.941 & 41.104 & 52.777 \\
\hline NLCA & SC Open & -0.90 & 1649 & 0.370 & -0.484 & -1.542 & 0.574 \\
\hline
\end{tabular}


Table 7. Asterias spp. Results of 1-way nested ANOVA applied to sea star arm length (mm) between closed and open areas on Georges Bank in 2003

\begin{tabular}{|lcrrrr|}
\hline Source & df & \multicolumn{1}{c}{ SS } & \multicolumn{1}{c}{ MS } & \multicolumn{1}{c|}{$F$} & \multicolumn{1}{c|}{ p } \\
\hline Fishery & 1 & 55062.07 & 55062.07 & 1.368 & 0.294 \\
Area & 5 & 626241.98 & 125248.40 & 364.259 & $<0.001$ \\
Residual & 4381 & 1506381.26 & 343.84 & & \\
\hline
\end{tabular}

primarily of sessile organisms that have adapted to the dynamic conditions of this area, but sea stars are scarce (Theroux \& Grosslein 1987, Stokesbury \& Harris 2006). Furthermore, the substrate in this area is predominantly granule pebbles and cobble, while Asterias spp. are generally associated with finer substrates more than gravel and till (Theroux \& Wigley 1998, Stokesbury 2002, Stokesbury et al. 2004, Stokesbury \& Harris 2006).

The highest sea star densities and the highest percentage of area covered by aggregations occurred in NLCA. In this area, the density of sea stars decreased significantly between 1999 and 2000 (Fig. 3). During the same period, granule pebble substrate decreased by over $50 \%$ and sand and shell debris increased, suggesting a large environmental shift possibly the result of a severe storm in September 1999 (Stokesbury \& Harris 2006, S. Hu pers. comm.). The density of sea stars increased over the next $3 \mathrm{yr}$, suggesting strong recruitment. The increased numbers of small individuals led to a decrease in average arm length.

Asterias forbesi and A. vulgaris are capable of assimilating large quantities of food, if food is abundant, resulting in increased individual size (Feder \& Moller-Christensen 1966). The size of sea stars was similar in the open and closed areas despite the higher abundance of sea scallops within the closed areas. Sea star predation may have been limited by the size of prey available (Paine 1976), as sea scallops were larger

Table 8. Placopecten magellanicus. Sea scallop instantaneous natural mortality rates $\left(\mathrm{yr}^{-1}\right)$ calculated using the number of live sea scallops and clappers observed by video survey and a shell ligament degradation rate of $1.58 \mathrm{yr}^{-1}$ (Merrill \& Posgay 1964). Area labels are defined in Table $1 ;-$ : no data collected

\begin{tabular}{|lccccc|}
\hline Area & 1999 & 2000 & 2001 & 2002 & 2003 \\
\hline CAI & 0.02 & 0 & 0.02 & - & 0 \\
CAIIN & 0.11 & - & 0.03 & - & 0.01 \\
CAIIS & - & - & 0.13 & - & 0.16 \\
GB OpenN & - & - & 0 & - & 0 \\
GB OpenS & - & - & - & - & 0.02 \\
NLCA & 0.18 & 0.08 & 0.02 & 0.02 & 0.04 \\
SC Open & - & 0.01 & 0.05 & 0.02 & 0.11 \\
\hline
\end{tabular}
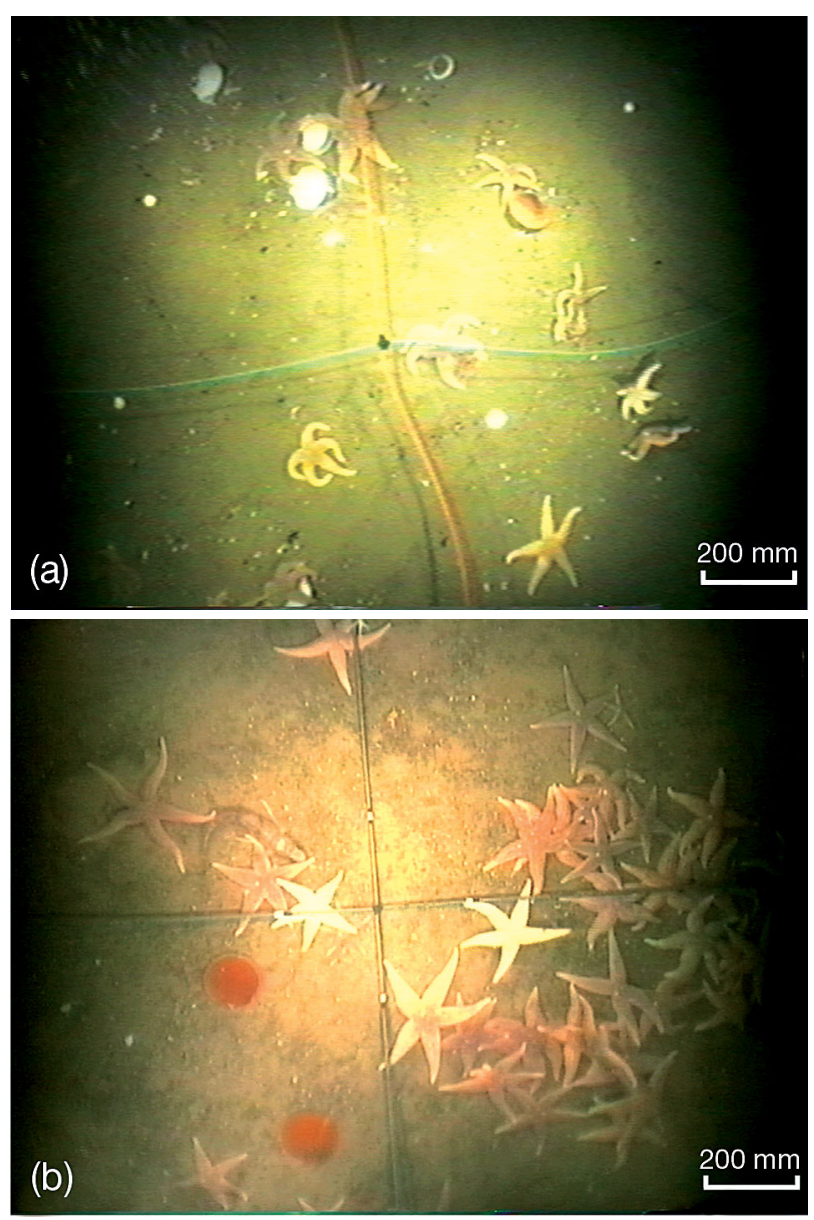

Fig. 5. Asterias spp. and Placopecten magellanicus. Intense sea star predation events (sea stars physically preying on scallops and at high densities) were observed in CAIIS in both (a) 2001 and (b) 2003

in the closed areas (2000: $t^{\prime}=48.48, \mathrm{p}=<0.001 ; 2001$ : $t^{\prime}=27.08, \mathrm{p}=<0.001 ; 2002: t^{\prime}=16.89, \mathrm{p}=<0.001$; 2003: $t^{\prime}=21.23, \mathrm{p}=<0.001$ using Welch's approximate $t$-test). For example, sea stars have strict limitations on the size and shape of their prey, although prey size generally increases with sea star size (Paine 1976, Anger et al. 1977). A. vulgaris must be at least 1.5 times the diameter of an oyster to successfully consume it (Needler 1941), and Dickie \& Medcof (1963) assume a similar ratio for sea scallops. Above the maximum sea scallop size, the sea star's muscle force is insufficient to open the shells or handling time becomes so long that it leads to energy loss (Feder \& Moller-Christensen 1966, Anger et al. 1977, O'Neil et al. 1983). Sea stars may form groups to feed on large bivalves to overcome this size limitation (Anger et al. 1977, Stokesbury \& Himmelman 1995).

Comparison of the observed distributions of sea star diameters to 1.5 times the shell height (Needler 1941) 
of sea scallops observed in the 2003 video survey (Stokesbury et al. 2004) indicates area-specific relationships. Approximately $6 \%$ of the sea scallop resource in each of the open areas was susceptible to sea star predation compared to 1,4 , and $13 \%$ of the sea scallops in NLCA, CAIIN, and CAI, respectively. Very large sea stars occurred in specific locations within the closed areas; for example, mean sea star arm lengths in the southern portion of CAII were consistently larger than in the open areas from 2001 to 2003. Therefore, the entire sea scallop resource in CAIIS was susceptible to sea star predation.

Estimates of instantaneous natural mortality rates based on the ratio of live scallops to clappers ranged from 0.00 to 0.18 , and varied markedly at different sites. We observed the highest instantaneous natural mortality rate (0.16) at CAIIS in 2003, equal to an annual natural mortality rate of $15 \%$. A rate of 0.10 for scallops with shell heights $>40 \mathrm{~mm}$ is used to manage the entire sea scallop resource, also based on a live scallop-to-clapper ratio (Merrill \& Posgay 1964, Hart 2003). Departures from this constant natural mortality $(M=0.10)$ can result in differences in the yield per recruit model (Hart 2003). Further, the clapper ratio only reflects a portion of natural mortality and does not include losses from crustaceans and fishes during which the shells are separated (Stokesbury \& Himmelman 1995).

In conclusion, the present study revealed high variation in the degree to which sea stars are aggregated on Georges Bank. Sea stars were aggregated in the closed areas, which may influence sea scallop densities. However, there was no clear influence of sea scallops on sea star distributions; instead, sea star predation due to the increase in soft tissue added to the environment coupled with sea star recruitment may have augmented the number of sea stars in the closed areas. In the future, as spatially explicit management areas and marine protected area management plans are implemented, it is important to consider spatial and temporal effects of predator populations.

Acknowledgements. We thank B. J. Rothschild for his support and guidance. We thank the owners, Captains, and crews who sailed with us on the FV 'Alpha and Omega II', FV 'Edgartown', FV 'Friendship', FV 'Frontier', FV 'Guidance', FV 'Huntress', FV 'Liberty', FV 'Mary Anne', FV 'Nordic Pride', and FV 'Tradition'. P. Christopher (NMFS) and L. Gavlin (USCG) provided the Letters of Authorization. M. Allard, C. Campbell, B. Harris, K. Hutchinson, T. Jaffarian, A. MacDonald, J. Nogueira, and C. Sarro provided technical support. S. X. Cadrin, J. T. Turner and 4 anonymous reviewers reviewed and provided many helpful comments, which greatly improved the manuscript. This research was supported by the Cooperative Marine Education and Research (CMER) program of NOAA (UMA/NOAA-NA17FE2738). Aid in the collection of these data was provided by the University of Massachusetts School for Marine Science \& Technology
(SMAST), the Massachusetts Department of Marine Fisheries, NMFS's sea scallop research set-aside program (NA16FM1031, NA06FM1001, NA16FM2416, and NA04NMF 4720332) and the sea scallop fishery and supporting industries. The views expressed herein are those of the authors and do not necessarily reflect the views of NOAA or any other agencies.

\section{LITERATURE CITED}

Anger K, Rogal U, Shriever G, Valentin C (1977) In-situ investigations on the echinoderm Asterias rubens as a predator of soft-bottom communities in the western Baltic Sea. Helgol Mar Res 29:439-459

Barbeau MA, Scheibling RE (1994) Behavioral mechanisms of prey selection by sea stars (Asterias vulgaris Verrill) and crabs (Cancer irroratus Say) preying on juvenile sea scallops (Placopecten magellanicus (Gmelin)). J Exp Mar Biol Ecol 180:103-135

Barbeau MA, Hatcher BG, Scheibling RE, Hennigar AW, Taylor LH, Risk AC (1996) Dynamics of juvenile sea scallop (Placopecten magellanicus) and their predators in bottom seeding trials in Lunenburg Bay, Nova Scotia. Can J Fish Aquat Sci 53:2494-2512

Barker MF, Nichols D (1983) Reproduction, recruitment and juvenile ecology of the starfish, Asterias rubens and Marthasterias glacialis. J Mar Biol Assoc UK 63:745-765

Brand AR (1991) Scallop ecology: distributions and behaviour. In: Shumway SE (ed) Scallops: biology, ecology and aquaculture. Elsevier, Amsterdam, p 517-584

Caddy JF (1989) A perspective on the population dynamics and assessment of scallop fisheries, with special reference to sea scallop, Placopecten magellanicus (Gmelin). In: Caddy JF (ed) Marine invertebrate fisheries: their assessment and management. John Wiley \& Sons, New York, p 559-589

Cliché G, Giguere M, Vigneau S (1994) Dispersal and mortality of sea scallops, Placopecten magellanicus (Gmelin, 1791), seeded on the sea bottom off Iles-de-la-Madeleine. J Shellfish Res 13:565-570

Cochran WG (1977) Sampling techniques. John Wiley \& Sons, New York

Day RW, Quinn GP (1989) Comparisons of treatments after an analysis of variance in ecology. Ecol Monogr 59(4): 433-463

Dickie LM (1955) Fluctuations on the abundance of the giant scallop Placopeten magellanicus (Gmelin) in the Digby area of the Bay of Fundy. J Fish Res Board Can 12(6): 797-857

Dickie LM, Medcof JC (1963) Cause of mass mortalities of scallops (Placopecten magellanicus) in the southwestern Gulf of St. Lawrence. J Fish Res Board Can 20:451-482

Elliott JM (1971) Some methods for the statistical analysis of samples of benthic invertebrates. Sci Pub 25. Freshwater Biological Association, Ambleside

Feder H, Moller-Christensen A (1966) Aspects of asteroid biology. In: Boolootian RA (ed) Physiology of Echinodermata. Interscience Publishers, New York, p 87-127

Flag CN (1987) Hydrographic structure and variability. In: Backus RH, Bourne DW (eds) Georges Bank. Massachusetts Institute of Technology, Cambridge, MA, p 108-124

Franz DR, Workley EK, Merrill AS (1981) Distribution patterns of common seastars of the middle Atlantic continental shelf of the Northwest Atlantic (Gulf of Maine to Cape Hatteras). Biol Bull 160:394-418

Hart DR (2003) Yield- and biomass-per-recruit analysis for rotational fisheries, with an application to the Atlantic sea 
scallop (Placopecten magellanicus). Fish Bull 101:44-57

Huitema BE (1980) The analysis of covariance and alternatives. Wiley Interscience, New York

Krebs CJ (1999) Ecological methodology, 2nd edn. Addison Wesley Longman, New York

Merrill AS, Posgay JA (1964) Estimating the natural mortality rate of sea scallop (Placopecten magellanicus). ICNAF Res Bull 1:88-106

Murawski SA, Brown R, Lai HL, Rago PJ, Hendrickson L (2000) Large-scale closed areas as a fishery-management tool in temperate marine ecosystems: the Georges Bank experience. Bull Mar Sci 66:775-798

Needler AWH (1941) Oyster farming in easter Canada. Bull Fish Res Board Can 60:1-83

NMFS (National Marine Fisheries Service) (1999-2001) Georges Bank sea scallop exemption fishery (a preliminary monitoring report). NOAA, NMFS, Northeast Regional Office, Gloucester, MA

O'Neil SM, Sutterlin AM, Aggett D (1983) The effects of sizeselective feeding by starfish (Asterias vulgaris) on the production of mussels (Mytilus edulis) cultured on nets. Aquaculture 35:211-220

Orensanz JM, Parma AM, Iribarne OO (1991) Population dynamics and management of natural stocks. In: Shumway SE (ed) Scallops: biology, ecology and aquaculture. Elsevier, Amsterdam, p 625-713

Paine RT (1976) Size-limited predation: an observational and experimental approach with the Mytilus-Pisaster interaction. Ecology 57:635-644

Parsons GJ, Roff JC, Dadswell MJ (1989) Influence of environmental factors on the maximization of spat settlement in the giant scallop, Placopecten magellanicus. J Shellfish Res 8(2):458

Ramsay K, Kaiser MJ, Hughes RN (1998) The responses of benthic scavengers to fishing disturbance by towed gears in different habitats. J Exp Mar Biol Ecol 224:73-89

Sloan NA (1984) Interference and aggregation: close encounters of the starfish kind. Ophelia 23:23-31

Editorial responsibility: Otto Kinne (Editor-in-Chief), Oldendorf/Luhe, Germany
Stokesbury KDE (2002) Estimation of sea scallop abundance in closed areas of Georges Bank, USA. Trans Am Fish Soc 131:1081-1092

Stokesbury KDE, Harris BP (2006) Impact of limited shortterm sea scallop fishery on epibenthic community of Georges Bank closed areas. Mar Ecol Prog Ser 307:85-100

Stokesbury KDE, Himmelman JH (1995) Biological and physical variables associated with aggregations of the giant scallop Placopecten magellanicus. Can J Fish Aquat Sci 52:743-753

Stokesbury KDE, Harris BP, Marino MC II, Nogueira JI (2004) Estimation of sea scallop abundance using a video survey in off-shore US waters. J Shellfish Res 23:33-44

Theroux RB, Grosslein MD (1987) Benthic fauna. In: Backus RH, Bourne DW (eds) Georges Bank. MIT Press, Cambridge, MA, p 108-124

Theroux RB, Wigley RL (1998) Quantitative composition and distribution of the macroinvertebrate fauna of the continental shelf ecosystems of the northeastern United States. US Dep Commer, NOAA Tech Rep NMFS 140

Underwood AJ (1981) Techniques of analysis of variance in experimental marine biology and ecology. Oceanogr Mar Biol Annu Rev 19:513-605

Underwood AJ (1997) Experiments in ecology. Cambridge University Press, Cambridge

Volkov YP, Dadaev AA, Levin VS, Murakhveri AM (1983) Changes in the distribution of Yezo scallop and starfishes after mass planting of scallops at the bottom of Vityaz Bay (Sea of Japan). Sov J Mar Biol 8:216-223

Wilson UAW, Brand AR (1993) Nowhere to hide? Predator impact on seeded scallops. Can Tech Rep Fish Aquat Sci 2:118

Wong MC, Barbeau MA (2003) Effects of substrate on interactions between juvenile sea scallops (Placopecten magellanicus Gmelin) and predatory sea stars (Asterias vulgaris Verrill) and rock crabs (Cancer irroratus Say). J Exp Mar Biol 287:155-178

Zar JH (1999) Biostatistical analysis, 4th edn. Prentice Hall, Upper Saddle River, NJ

Submitted: June 19, 2006; Accepted: May 16, 2007

Proofs received from author(s): September 26, 2007 